\title{
DEVELOPMENT EXACTIONS AND IMPACT FEES: A SURVEY OF AMERICAN PRACTICES
}

\author{
Gus Bauman* \\ and William H. EThier $†$
}

I

\section{INTRODUCTION}

One of the hottest issues in the land use arena is the expanding implementation of development exactions and impact fees. Although impact fees have existed for several years, and development exactions even longer, 1 their use by local governments has greatly increased during this decade. Regarding fees in particular, planners, developers, and lawyers are wrestling with the validity of these new sources of municipal funds and their application to an ever expanding set of purposes.

The proliferation of impact fees and development exactions (especially offsite exactions) is due to several factors. Federal funding to state and local governments through revenue sharing and other grant programs is drying up. The continuing suburbanization of the nation's population and the rapid rate of new household formation require local governments to extend services to new and larger areas. In high growth areas in particular, government is hardly able to keep pace with the demand for new services while simultaneously maintaining and repairing existing public facilities. In addition, compliance with stringent government mandated standards often requires substantial public outlays and unpopular financing decisions.

Traditionally, local government has financed public services through general revenues and the issuance of general obligation bonds that are pledged against local property tax collections. In the present economic climate, however, the condition of the bond market and the competition

Copyright $\odot 1987$ by Law and Contemporary Problems

* Litigation Counsel, National Association of Home Builders, Washington, D.C.

$\dagger$ Associate Litigation Counsel, National Association of Home Builders, Washington, D.C.

We received helpful assistance from Wendy Dworshak and Anthony Dillon, Law Clerks; Gopal Ahluwalia, Director of Research, Economics Division; and Carol Soble, State and Local Government Affairs Director, National Association of Home Builders. Thanks also to Richard Babcock's thirdyear law students at Duke University, Arthur Adler, Seth Bernanke, Donald Gotcher, Lyndall Huggler, Chris Mangun, Robert Moxley III, and Campbell Tucker III, who tabulated the original survey's raw numbers. The views in this article are those of the authors and not necessarily those of the Association.

1. Examples of development exactions appeared in colonial ordinances and royal directives. See Ferguson \& Rasnic, Judicial Limitations on Mandatory Subdivision Dedications, 13 ReAl. EsT. L.J. 250, 252 (1984). 
among investment options has made the marketing of debt instruments more difficult for a number of jurisdictions, even for those with sound credit ratings. Another complication arises from state mandated limitations on bonded indebtedness, which restrict the dollar volume of debt issued.

Existing taxpayers in many jurisdictions have grown unwilling to share the cost of providing services to new residential development through property taxes that secure general obligation debt. They see little reason for paying the way of newcomers, especially when tax levies appear to rise without a commensurate increase in service levels. It is understandable, then, that the passage of several tax cutting measures, including California's Proposition $13^{2}$ and Massachusetts' Proposition $2 \frac{1}{2},{ }^{3}$ has attracted national attention as a possible way of reconciling inflation-eroded state and local budgets and reducing the scope of government and government supported services.

One consequence of the popularly termed "taxpayer revolt" is the emergence of local governmental policy that deems residential development acceptable only if it can "pay its own way." Decision makers are frequently reluctant to approve development proposals that would require significant and politically unpopular outlays for service expansion. If they do approve development, local policy makers increasingly condition permission to build on the payment of impact fees, effectively shifting responsibility for providing services and facilities from the public to the private sector. For prospective new home buyers and tenants, these fees represent a condition of residency in a community. But too often policy makers view the costs and benefits of development only in the short term, rather than looking to the time of project completion, when enhanced property taxes are regularly collected. More importantly, secondary and tertiary community-wide benefits, which are difficult to quantify, are frequently overlooked at the time of plat or permit application. These benefits include growth in retail sales and sales tax collection, expanded employment opportunities, increased disposable income, and diversity in housing choices.

This article first outlines the policy and legal issues that require consideration by those who review exaction schemes. It then presents the findings of a new survey of national development exaction practices.

\section{II}

\section{Some Preliminary Considerations}

The fundamental issue raised by the new kinds of development exactions and impact fees, as the connection between the needs created by new development and the exactions required of it become more attenuated, is that of equity. How much of the costs of new or upgraded public facilities should a community's newcomers or the children of existing residents entering the housing market bear vis-a-vis the existing residents? After all, "[ $t$ ]he number

2. Cal. Const. art. XiIIA (1978).

3. Mass. Gen. Laws AnN. ch. 59, § $21 \mathrm{C}$ (West Supp. 1986). 
and types of subdivision improvements that a local government can require a developer to complete are limited only by the imaginations of the members of the planning commission and the local governing body." 4 That local governments are virtually unrestrained with respect to subdivision exactions is certainly politically understandable, since existing taxpayers (the voters) are a present reality, while new consumers are dispersed and unorganized.

\section{A. Policy Questions}

Government officials, business leaders, and other interested citizens should consider several policy questions when determining whether or how to structure an exaction or fee program..$^{5}$ First, can imposition of the exaction be reconciled with the community's housing and development goals as stated in its master plan? High fees and excessive exactions that rise above the direct public cost of providing services for new development put a severe strain on the tenability of an affordable housing market. Thus, policy makers must determine whether decreased housing opportunities for employees will deter business or industry from entering or expanding in a community.

Second, will lowering certain local development standards mitigate the adverse impact on housing affordability of fees or other exactions? For example, decreased minimum lot sizes, house size restrictions, road width requirements, and increased use of cluster developments can achieve considerable cost savings, particularly when combined with other reformed building and development measures, without imperiling reasonable health and safety standards. ${ }^{6}$

Third, has the "lumpiness" of public investment been taken into account? In the opening years of the life cycle of a public facility, costs usually exceed revenues. But as more customers are brought on line, the cost-revenue gap narrows significantly. The long-term generation of revenue through property, income, and sales taxes often balances out any short-term capital operating deficits.

Fourth, is the purpose of the exaction to meet valid fiscal necessities or to mask an unofficial exclusionary policy? For example, one might question whether the local sewer plant is truly operating at capacity, or if a "raise-thedrawbridge" mentality is really at work. Facing frankly not only economic considerations but also political pressures should lead to a more honest appraisal of the proper community policy.

4. Shultz \& Kelley, Subdivision Improvement Requirements and Guarantees: A Primer, 28 WASH. U.J. URB. \& Contemp. L. 3, 39 (1985).

5. See Currier, Legal and Practical Problems Associated with Drafting Impact Fee Ordinances, 1984 INST. on Plan. Zoning \& Eminent Domain 273, 274-80.

6. Since 1982, the U.S. Department of Housing and Urban Development (HUD), through the Office of Policy Development and Research, has been conducting a demonstration program called the Joint Venture for Affordable Housing. Its goal is to show with actual housing developments how reformation of certain building and land use regulations can translate into significant savings for the consumer. Currently active in approximately 40 communities nationwide, the aim is to have a demonstration project in every state. Case studies on the results of each development are then published by HUD. 
Finally, is the exaction policy premised on a fair share principle? Just as one of the Mt. Laurel decisions? stands for the "municipal obligation to provide a realistic opportunity for low- and moderate-income housing," 8 such a goal would remain a somewhat futile promise if not also applied to expanded development exactions. Residential impact fees, in particular, raise the double taxation problem. Both existing and new home owners pay property taxes, which are deductible. Yet through the purchase price of their homes, new owners must also pay nondeductible impact fees, which increase the cost of home financing over the life of the mortgage. As a result, under many schemes, new owners pay twice for the same public services existing owners pay for once, and only the property tax payment is deductible.

\section{B. Legal Issues}

The typical legal issues underlying development exactions and impact fees are basically the same. Because impact fees constitute a general funding mechanism not necessarily tied to the subdivision process, however, they raise additional questions that courts are now addressing. ${ }^{9}$ Essentially, fees must be authorized by state law and must be constitutional. An impact fee imposed by a local agency and not authorized by law will be struck down. ${ }^{10}$ Another key authority issue is whether the fee is really a tax. A local government's authority to impose fees derives from the state's police power to regulate development for the public's health, safety, or general welfare, while the more restricted taxing power is for the express purpose of raising general revenue. If a fee amount is not reasonably equivalent to the cost of the regulated activity, or if the monies collected are deposited into the general treasury rather than a special fund, the fee may be deemed a tax and therefore illegally adopted. ${ }^{11}$

Impact fees raise several constitutional issues: equal protection, due process, and the taking of private property without just compensation. Impact fees may be vulnerable to attack that they are discriminatory, for example, if levied against new development for public facilities that serve both new and old users of a system, or if differential fee structures assess types of users in a nonuniform fashion. (An example of the second type of impact fee is a sewer fee on residential, but not commercial, development or on

7. Southern Burlington County NAACP v. Township of Mt. Laurel, 92 N.J. 158, 456 A.2d 390 (1983).

8. Id., at $216,456 \mathrm{~A} .2 \mathrm{~d}$ at 419 .

9. For a review of subdivision exaction legal standards covering on-site, off-site, and fee in lieu of dedication requirements, see Note, Subdivision Exactions: A Review of Judicial Standards, 25 WASH. U.J. URB. \& CONTEMP. L. 269 (1983). For a more general review of decisions on traditional, modern, and "futuristic" exactions handed down between 1980 and 1983, see Bley, Exactions in the 1980s, 1984 Inst. on Plan. Zoning \& Eminent Domain 297.

10. See, e.g., Washington Suburban Sanitary Comm'n v. C.1. Mitchell \& Best Co., 303 Md. 544, 495 A.2d 30 (1985).

11. See, e.g., Emerson College v. City of Boston, 391 Mass. 415, 462 N.E.2d 1098 (1984); Hillis Homes, Inc. v. Snohomish County, 97 Wash. 2d 804, 650 P.2d 193 (1982) (superseded byWash. Rev. Code AnN. \$ 82.02.020 (Supp. 1987)). 
multifamily housing only.) For the most part, however, constitutional questions focus on the reasonableness of a fee under the due process clause. Most courts determine whether a reasonable connection exists between the charges required of and the benefits conferred upon a new development ${ }^{12}$ by focusing on such questions as: Is the fee excessive? Are the funds segregated in a special account or deposited in the general treasury? Are the funds spent for the designated service in geographically defined zones or districts, or can they be spent anywhere in the community? If collected monies are not spent within a reasonable time, are they reimbursed or credited to the exacted party? Finally, if an exaction denies a person the use of his property, a court may decide that a taking has occurred. The best example is the indefinite reservation of private land for some future public use, such as a proposed highway. ${ }^{13}$

\section{III}

\section{Survey of Development Exaction and Fee Practices}

A survey of current development exaction and impact fee practices was conducted between December, 1984, and March, 1985. Survey forms were sent to 1,000 communities. ${ }^{14}$ Completed surveys from 220 communities in 46 states were returned, an excellent $22 \%$ response rate. A handful of unresponsive surveys were returned, which were not tabulated in the results. ${ }^{15}$ Although the results below may not give a statistically perfect picture of exaction policies, the data received provide the most comprehensive national information analyzed to date.

Defining the terms "on-site" and "off-site exactions," "in-lieu fees," and "impact fees" is necessary for discussing the practice and extent of these financing tools. The terminology is sometimes confusing, with varying meanings in different communities. One of the survey respondents, a city planner from Texas, pointed out that Webster's Dictionary defines the term "exaction" as "extortion"16 and scrawled across the survey, "We do not extort fees." The New Hampshire Supreme Court agrees with Webster's definition and invalidated a development exaction as amounting to extortion. ${ }^{17}$ Characterizing a development exaction as extortion evinces not

12. Florida courts are very specific as to which fee ordinances pass muster and which do not. See Currier, supra note 5, at 284-89. California courts, on the other hand, are the most open-ended with regard to what is permitted. See 1 N. Williams, American Land Planning Law $\$ 6.03$ (1974).

13. See Gordon, Subdivision Exactions Draw Challenges from Developers, Legal Times of Wash., Sept. 2, 1985, at A4, col. 3. The United States Supreme Court recently noted probable jurisdiction in an exaction case (involving not fees but beach access) that raises the taking issue. Nollan v. California Coastal Comm'n, 177 Cal. App. 3d 719, 223 Cal. Rptr. 28, prob. juris. noted, 107 S. Ct. 312 (1986). See Strasser, Just Whose Land Is It-Anyway?, NAT'L L.J., Dec. 22, 1986, at 1, col. 3.

14. The communities chosen were those that subscribe to the American Planning Association's Planning Advisory Service.

15. A list of the responding communities appears in the Appendix to this article, infra p. 65.

16. Webster's Ninth New Collegiate Dictionary 431 (1986).

17. J.E.D. Assocs. v. Town of Atkinson, 121 N.H. 581, 584, 432 A.2d 12, $14-15$ (1981); accord Collis v. City of Bloomington, 310 Minn. 5, 17, 246 N.W.2d 19, 26 (1976). The national planning profession has not lost sight of the "extortion" attraction. At the 1985 conference of the American 
only the emotions aroused by the exaction issue but also a problem with the terminology.

The generally accepted definition among land use practitioners of a traditional development exaction is a governmental requirement that a developer dedicate or reserve land for public use or improvements, or pay a fee in lieu of dedication, which is used to purchase land or construct public improvements. Development exactions are normally part of the subdivision process and are conditions developers must meet in order to obtain approval of their plats. Although most exactions are imposed for on-site purposes, such as internal streets or local school sites, they may also be used for off-site purposes if related in some degree to the service needs created by the subdivision.

A new kind of exaction is the impact fee. Impact fees are charges levied against a new development in order to generate revenue for funding capital improvements presumably necessitated by that development. As a funding mechanism, impact fees are more flexible than subdivision exactions because they are not limited to the subdivision process. The fees are usually levied at the time of building permit issuance for residential, commercial, or industrial projects. As such, impact fees are more readily adaptable to fund the construction of off-site facilities. They are calculated through a formula, such as the number of bedrooms in a dwelling or square feet in a building, or by a flat rate, such as per dwelling unit or building permit.

\section{A. General Policies Regarding Exactions and Impact Fees}

Table 1 shows that communities with populations of less than 50,000 represented $47.7 \%$ of the survey respondents. The response rate decreased as community size increased.

TABLE 1

Responses by Population of Community

\begin{tabular}{lcccccc}
\hline & $\begin{array}{c}\text { Less than } \\
50,000\end{array}$ & $\begin{array}{c}50,000- \\
99,999\end{array}$ & $\begin{array}{c}100,000- \\
249,999\end{array}$ & $\begin{array}{c}250,000- \\
499,999\end{array}$ & $\begin{array}{c}500,000 \\
\text { \& over }\end{array}$ & $\begin{array}{c}\text { All } \\
\text { Communities }\end{array}$ \\
\hline $\begin{array}{l}\text { Number of } \\
\text { responses }\end{array}$ & 105 & 51 & 47 & 12 & 5 & 220 \\
\hline $\begin{array}{l}\text { Percentage of } \\
\text { total responses }\end{array}$ & 47.7 & 23.2 & 21.4 & 5.5 & 2.3 & $100.1^{*}$ \\
\hline
\end{tabular}

- Does not equal $100 \%$ due to rounding

Planning Association, one of six sessions dealing with developer "contributions" to public infrastructure and subsidized housing was entitled "Extortion in the Public Interest." The session's speakers "seemed to worry less about how such contributions occurred than about what the community could get from them." The Miami planning director, for instance, "outlined Miami's proffer system, whereby many developers on their way to project approval somehow sense the public's need for all manner of plazas, escalators, interstate highway construction, police and fire improvements, and other facilities." Porter, Exactions, Extractions, and Extortions, Urb. Land, Aug. 1985 , at $36,36-37$. 
Table 2 breaks down the number of responses by the total number of housing starts in a community, a much better indicator of growth than community population. This breakdown yielded a more even distribution of responses.

TABLE 2

\section{Responses by Total Number Housing Starts in the Community FOR 1984}

\begin{tabular}{lccccccc}
\hline & $\begin{array}{c}\text { Less than } \\
50\end{array}$ & $\begin{array}{c}50- \\
99\end{array}$ & $\begin{array}{c}100- \\
499\end{array}$ & $\begin{array}{c}500- \\
999\end{array}$ & $\begin{array}{c}1,000 \\
\text { \& over }\end{array}$ & $\begin{array}{c}\text { No } \\
\text { Response }\end{array}$ & $\begin{array}{c}\text { All } \\
\text { Communities }\end{array}$ \\
\hline $\begin{array}{l}\text { Number of } \\
\text { responses }\end{array}$ & 43 & 21 & 73 & 24 & 43 & 16 & 220 \\
\hline $\begin{array}{l}\text { Percentage of } \\
\text { total responses }\end{array}$ & 19.5 & 9.5 & 33.2 & 10.9 & 19.5 & 7.3 & $99.9^{*}$ \\
\hline
\end{tabular}

* Does not equal $100 \%$ due to rounding

The survey results show that $65.9 \%$ of all responding communities have some type of formal policy regarding on-site development exactions. A formal policy means a set standard by which the community makes decisions, supposedly in a consistent manner, about exactions or impact fees. (The informal approach exists where exactions or fees are required on an ad hoc, project-byproject basis.) A significantly lower percentage of communities have formal policies regarding off-site exactions $(39.6 \%)$ or impact fees $(36.4 \%)$.

In those communities having a formal policy regarding exactions or impact fees, the policy most often ( $68.2 \%$ of the time) takes the form of an ordinance. Another $16.6 \%$ of the respondents said their formal policy is part of a master or comprehensive plan, and $5.1 \%$ reported that their formal policy is unwritten (which seems a contradiction in terms). The remaining $10.2 \%$ reported that their formal policy is not part of a plan or ordinance, or did not respond to this question.

In addition to those communities having formal policies on off-site exactions or impact fees, another $18.2 \%$ impose off-site exactions, and $9.0 \%$ impose impact fees on a project-by-project basis. ${ }^{18}$ Therefore, $57.8 \%$ of the responding communities have off-site exactions and $45.4 \%$ have impact fees, either by adopting a formal policy or by using a project-by-project approach.

B. Development Exaction Requirements-Dedications, Reservations, and In-Lieu Fees

The survey results also yielded an in-depth picture of off-site exaction requirements, but not all communities with formal exaction policies have

18. In 1984, the Urban Land Institute surveyed a small number of developers who had provided exactions in a variety of projects. Developers of 52 projects nationwide responded. "Almost onethird of the projects contributed off-site exactions, most of which, except where fees were required, were negotiated rather than specified in regulations. ... In addition to the 'standard' exactions, project developers were required to contribute such facilities as a pedestrian tunnel, a freeway sound wall, a portable library, and a golf course." Porter, supra note 17, at 37. 
implemented them. The following figures represent those communities that actually impose exactions pursuant to their formal policies. Therefore, the numbers are slightly lower than those relating to the mere existence of a formal policy.

A little over one-third of the respondents (35.9\%) impose some type of off-site exactions, either land dedications, reservations, or fees in lieu of dedication. However, when categorized into the specific purposes for which the exaction is imposed, the result differs. The percentage of those communities imposing off-site exactions for the following purposes are: schools, $56.6 \%$; roads, $45.9 \%$; parks and recreation, $40.9 \%$; libraries, $12.4 \%$; public safety, $8.4 \%$; and other purposes, $20.1 \%$.

On-site land dedications, reservations, or in-lieu fees for all purposes are required by roughly the same percentage of communities $(35.8 \%)$ that impose off-site exactions. The breakdown by purpose is as follows: roads, $75.3 \%$; parks and recreation, $55.5 \%$; schools, $26.8 \%$; public safety, $10.6 \%$; libraries, $7.3 \%$; and other purposes, $32.8 \%$.

With respect to land dedication requirements, both off-site and on-site dedications are required more often for roads $(28.0 \%$ and $60.1 \%$, respectively) than for any other purpose. With respect to in-lieu fees, off-site fees are required most often for school purposes $(51.0 \%)$, and on-site fees are required most often for parks and recreation facilities $(15.8 \%)$.

Less than $10 \%$ of the communities reported methods of assessing both offsite and on-site exactions based on the number of bedrooms, lot size, or house size, a sample statistically too small to give the numbers much meaning. On the other hand, a flat rate assessment is used by $30.9 \%$ of the communities to calculate off-site exactions and $23.5 \%$ to calculate their on-site requirements. A majority of the respondents did not elaborate on their methods of assessment.

\section{Impact Fee Requirements}

These newer types of fees should be distinguished from the more narrowly applied fees in lieu of land dedication. Some localities charge both types of fees. As stated above regarding traditional development exactions, the following figures represent those communities that actually impose impact fees pursuant to their formal policies.

Impact fees are required by $36.6 \%$ of the communities for sewer facilities, $33.5 \%$ for water facilities, $30.8 \%$ for roads, $30.8 \%$ for parks and recreation, $13.5 \%$ for schools, and $34.6 \%$ for other purposes. Like the method for traditional exactions, respondents most often identified the flat rate as the assessment method for calculating impact fees. Just over $92 \%$ of the respondents' impact fees are deposited in a special fund. The remaining 17 localities use their assessed fees for general revenue purposes, which makes them look like general revenue raising taxes, not regulatory fees. ${ }^{19}$ Those 17

19. See supra text accompanying note 11 . 
communities span the range of community sizes and number of housing starts and are from all regions of the country.

There has been a significant increase in the incidence of impact fees over the last few decades. According to the survey results, 35.0\% of all current impact fee policies were enacted between 1980 and 1985. An additional $36.0 \%$ were enacted in the 1970's and $18.7 \%$ in the 1960's. Only $10.3 \%$ of current impact fee policies existed before 1960 .

\section{Survey by Geographic Region and Cost Per Unit}

The 220 survey respondents were also broken down by region. ${ }^{20} \mathrm{~A}$ large number of respondents were from California, and responses from that state were separated in order not to skew the regions' numbers. The percentage of communities by region having formal exaction or impact fee policies is shown in Table 3. The most notable differences between regions are that New England and the Mid-Atlantic have a relatively low number of impact fees, and California has a relatively high number of impact fees and off-site exactions.

TABLE 3

Percentage of Communities with Formal Policy by Region

\begin{tabular}{|c|c|c|c|c|c|c|}
\hline & $\begin{array}{c}\text { Percentage } \\
\text { with } \\
\text { Off-Site } \\
\text { Exactions } \\
\end{array}$ & $\begin{array}{l}\text { (Number of } \\
\text { Affirmative } \\
\text { Responses) }\end{array}$ & $\begin{array}{c}\text { Percentage } \\
\text { with } \\
\text { On-Site } \\
\text { Exactions }\end{array}$ & $\begin{array}{l}\text { (Number of } \\
\text { Affirmative } \\
\text { Responses) }\end{array}$ & $\begin{array}{c}\text { Percentage } \\
\text { with } \\
\text { Impact Fees }\end{array}$ & $\begin{array}{l}\text { (Number of } \\
\text { Affirmative } \\
\text { Responses) }\end{array}$ \\
\hline New England & 36.4 & $(4)$ & 45.5 & (5) & 0 & $(0)$ \\
\hline Mid-Atlantic & 40.0 & ( 6$)$ & 46.7 & ( 7 ) & 13.3 & ( 2$)$ \\
\hline South & 22.2 & (12) & 61.1 & (33) & 27.8 & (15) \\
\hline Midwest & 36.5 & (23) & 65.1 & (41) & 23.8 & (15) \\
\hline West & 47.7 & (21) & 75.0 & (33) & 45.5 & (20) \\
\hline California & 63.6 & (21) & 69.7 & (23) & 81.8 & (27) \\
\hline
\end{tabular}

The average cost per unit for off-site exactions by region and purpose is shown in Table 4. Unfortunately, very few responses to the cost questions were received. Communities either refused to say or did not know what the

20. The breakdown is as follows:

TABle

STATES BY REgION

$\underline{\text { Region }}$

$\underline{\text { States }}$

Number of

New England

Conn., Me., Mass., N.H., R.I., Vt.

Communities

Mid-Atlantic

Del., Md., N.J., N.Y., Pa., W.Va.

11

South

Ala., Ark., Fla., Ga., Ky., La., Miss., N.C., S.C., Tenn., Va.,

15

Tex.

54

Midwest

Ill., Ind., Iowa, Kan., Mich., Minn., Mo., Neb., N.D., Ohio,

63

West Okl., S.D., Wis.

Alaska, Ariz., Colo.
Utah, Wash., Wyo.

California 
per housing unit costs of their exactions were. ${ }^{21}$ The most notable cost figures are those for parks and recreation. Park exactions in California cost three times per unit what they cost in the Midwest and remainder of the West. 22

TABLE 4

Average Cost Per Unit of Off-Site Exactions

\begin{tabular}{|c|c|c|c|c|c|c|c|}
\hline & $\begin{array}{l}\text { Parks \& } \\
\text { Recreation }\end{array}$ & Schools & Libraries & Roads & $\begin{array}{l}\text { Public } \\
\text { Safety }\end{array}$ & Sewers & $\begin{array}{l}\text { Flood } \\
\text { Control }\end{array}$ \\
\hline $\begin{array}{l}\text { New England and } \\
\text { Mid-Atlantic }\end{array}$ & \multicolumn{7}{|c|}{ no responses to cost questions } \\
\hline South & $\begin{array}{l}\$ 230.00 \\
(1)^{*}\end{array}$ & $\begin{array}{l}\$ 400.00 \\
\text { (1) }\end{array}$ & & & $\begin{array}{l}\$ 150.00 \\
(1)\end{array}$ & & \\
\hline Midwest & $\begin{array}{l}\$ 306.00 \\
(10)\end{array}$ & $\begin{array}{l}\$ 1044.00 \\
\text { (1) }\end{array}$ & & $\begin{array}{l}\$ 30.00 \text { per } \mathrm{ft} \text {. } \\
\text { (1) }\end{array}$ & & $\begin{array}{l}\$ 250.00 \\
\text { (1) }\end{array}$ & \\
\hline West & $\begin{array}{l}\$ 297.00 \\
(9)\end{array}$ & $\begin{array}{l}\$ 328.00 \\
(3)\end{array}$ & & $\begin{array}{l}\$ 835.00 \\
(3)\end{array}$ & $\begin{array}{l}\$ 122.00 \\
(1)\end{array}$ & $\begin{array}{l}\$ 531.00 \\
\text { (1) }\end{array}$ & \\
\hline California & $\begin{array}{l}\$ 987.00 \\
(9)\end{array}$ & $\begin{array}{l}\$ 1042.00 \\
(6)\end{array}$ & $\begin{array}{l}\$ 150.00 \\
\text { (1) }\end{array}$ & $\begin{array}{l}\$ 1141.00 \\
(5)\end{array}$ & $\begin{array}{l}\$ 102.50 \\
(2)\end{array}$ & $\begin{array}{l}\$ 743.50 \\
(2)\end{array}$ & $\begin{array}{l}\$ 125.00 \\
(2)\end{array}$ \\
\hline
\end{tabular}

* Number in parenthesis equals the number of responses

\section{E. Survey by Housing Starts}

As noted in Table 2,23 there was a fair distribution of responses with respect to the number of housing starts in a community for 1984. Table 5 shows the percentage of communities by housing starts that have either a formal policy on off-site exactions or impact fees or that have an informal, project-by-project approach. The survey results evidence a general increase in the percentage of communities requiring off-site exactions as the number of housing starts increase. The same cannot be said for impact fees. The percentage of communities by housing starts requiring off-site or on-site exactions for various public facilities is shown in Table 6.

21. In a 1984 survey by the Policy Sciences Program at Florida State University, 1,718 public works directors were surveyed on impact fees for sewer facilities. Seventy-two of the 190 directors that charged impact fees were from Florida and California communities. The average sewer impact fee was $\$ 689$ for a single-family home. See Porter, supra note 17 , at 36 .

22. California impact fees are high and have been steadily increasing. A 1982 survey of fees by the Association of Bay Area Governments revealed that median total development fees for the 9county San Francisco area increased $32 \%$ over the amounts charged in 1979. Totals ranged from $\$ 420$ to $\$ 8,568$, with a median of $\$ 3,490$ per housing unit.

A 1984 survey of southern California communities by the Construction Industry Research Board yielded similar figures. The average infrastructure impact fee (stated in 1983 dollars) per housing unit increased from $\$ 1,009$ in 1975 to $\$ 6,647$ in 1983. (Proposition 13 was enacted in 1978.) Average fees for roads, schools, and parks were $\$ 1,635, \$ 1,313$, and $\$ 1,128$ per unit, respectively. Fees per house ranged as high as $\$ 3,050$ for parks, $\$ 2,400$ for water, and $\$ 2,054$ for roads. Impact fees accounted for $7.5 \%$ of the average cost of a house. These survey results are reported in Califfornians for Housing, The Hidden Costs of Housing $11-12$ (1984).

23. See supra p. 57. 
TABLE 5

Percentage of Communities by Number of Housing Starts With Informal Approach or Formal Policy

\begin{tabular}{lccccc}
\hline & \multicolumn{5}{c}{ Number of Housing Starts (1984) } \\
\cline { 2 - 6 } & Less than 50 & $50-99$ & $100-499$ & $500-999$ & $1000+$ \\
\hline Off-site exactions & 51.2 & 57.2 & 61.6 & 58.4 & 74.3 \\
\hline Impact fees & 32.6 & 57.2 & 42.5 & 50.0 & 44.1 \\
\hline
\end{tabular}

TABLE 6

Percentage of Communities by Number of Housing Starts Requiring Exactions for Specific Purposes

\begin{tabular}{lccccc}
\hline & \multicolumn{5}{c}{ Number of Housing Starts (1984) } \\
\cline { 2 - 6 } Purpose of Exaction & Less than 50 & $50-99$ & $100-499$ & $500-999$ & $1000+$ \\
\hline Off-Site Exaction* & & & & & \\
Parks \& Recreation & 14.0 & 23.9 & 17.8 & 37.5 & 30.2 \\
Schools & $-0-$ & 14.3 & 19.3 & 20.8 & 18.6 \\
Libraries & $-0-$ & 4.8 & 2.7 & 8.3 & 2.3 \\
Roads & 30.2 & 33.3 & 38.4 & 41.7 & 51.2 \\
Public Safety & $-0-$ & 4.8 & 4.3 & 12.5 & 2.3 \\
Other & 4.7 & 4.8 & 13.7 & 16.7 & 11.6 \\
\hline On-Site Exaction & & & & & \\
Parks \& Recreation & 41.9 & 47.6 & 45.2 & 20.8 & 39.5 \\
Schools & 7.0 & 28.6 & 19.2 & 8.3 & 20.9 \\
Libraries & 2.3 & 4.8 & 5.5 & $-0-$ & 11.6 \\
Roads & 53.5 & 66.7 & 61.6 & 54.2 & 62.8 \\
Public Safety & 2.3 & 14.3 & 6.8 & $-0-$ & 14.0 \\
Other & 11.6 & 9.5 & 28.8 & 16.7 & 16.3 \\
\hline
\end{tabular}

* For off-site exactions, the sum of percentage figures in a housing starts column may be greater than the figure reported in Table 5 because many communities have exactions for more than one purpose.

\section{F. Respondents' Comments}

Seventy-one of the survey's respondents offered comments on the concept or practice of development exactions and fees. The comments break down into six general categories. No pattern based on geographic location or community size was evident within any of the categories.

Eleven community planners supported either the concept or practice of requiring exactions or fees, while six were negative in their remarks. Another sixteen were more neutral in tone, viewing exactions as a practical necessity. Thirteen respondents approved of the exaction concept and have exactions, but voiced some criticism of how their fees are assessed or allocated. Seventeen respondents made mention of relying on more traditional schemes 
in addition to fees and off-site requirements, such as requesting voluntary land dedication or annexing developed property. Finally, eight planners were noncommittal in their remarks because they felt that the terms "on-site exaction," "off-site exaction," "in-lieu-fee," and "impact fee" were too imprecise.

\section{IV}

\section{Conclusion}

Impact fees and the more extreme forms of development exactions are a fact of life in high growth states burdened with severely restricted tax systems, such as California and Florida. But now, many other communities in other states are following the lead of those two Sunbelt States. The exactions survey results reveal that impact fees, which are most prevalent in the West, particularly in California, are increasing both in frequency and in amount. From the local government's point of view, the most pressing matter often is how to raise more municipal funds or public improvements in lieu of taxes. From the housing consumer's point of view, the usually hidden issue is that of equity in treatment as compared with existing residents in a community. From the builder's point of view, the uncertainty surrounding what exactions will be required of any particular development proposal can be even more difficult to contend with than the actual amount extracted.

The first two viewpoints concern chiefly matters of economic and social policy, while the third viewpoint raises considerations of a more legal nature. A project-by-project approach to exaction policy, to which many survey respondents admitted, creates not only uncertainty, with all its financial ramifications, but also the possibility of uneven governmental treatment, as well as an arbitrary system for dealing with public facility requirements. Land use lawyer Fred Bosselman, a noted proponent of creative governmental controls, has recently pointed out that newer forms of exactions, which replace the rule of law with the rule of man, pose serious legal problems because what is gained in flexibility may be lost in inequity. ${ }^{24}$

The overriding aim of any exaction policy should be to allocate, as much as fairness dictates, to the general public the cost of facilities used by and benefiting the public. As part of that general public, the direct recipients of new development, represented by developers, new buyers, and tenants, should pay their fair share of the long-term costs of development (keeping in mind that existing residents are indirect recipients of development benefits). Anything that goes beyond a considered balancing of the community's need for public improvements, the consumer's need for equity, and the builder's need for a just certainty raises important constitutional and social issues.

24. Porter, supra note 17 , at 37. 


\section{ADDENDUM}

\section{A. Government Survey Update}

In March, 1986, the 220 communities originally surveyed were requested to provide updated information to their original responses. One hundred sixty-one replied, of which 25 reported substantive changes that resulted in new or additional exaction requirements. Nine others said they were considering the adoption of new requirements. None indicated repeal of any requirements. The 25 communities reporting changes came from 16 states representing every section of the country; 5 were in California, 4 in Colorado, and 2 each in Texas and Illinois.

The information from the 25 updating respondents was processed using two different frames of reference. The data were analyzed according to whether: (1) the requirements were new or amended; and (2) the community was imposing an exaction or impact fee. As to the first category, 23 of the requirements were newly adopted since the date of the original survey, 20 requirements were amendments of those originally reported, and 19 requirements involved information not reported on, although existing, at the time of the original survey.

Turning to the second category of information, 15 of the changed requirements involved off-site exactions, 20 concerned on-site exactions and 27 were impact fees. (The numbers generally exceed 25 because a single community may adopt, say, a road impact fee and a school impact fee, and amend its off-site parks exaction requirements, all at the same time).

Thus, of the 161 updating respondents, $21 \%$ reported that they have imposed tougher exaction and fee requirements or were considering their adoption in the period between March, 1985, and March, 1986. The greatest change was in the adoption of impact fees. This latest information reinforces what the original government survey disclosed.

\section{B. Builder Survey}

In a revealing and parallel development, a national telephone survey of 493 home builders on the subject of impact fees was recently conducted by Builder Magazine. ${ }^{25}$ Of the total number of builders, $213(43.2 \%)$ said they paid impact fees. (This figure is almost identical to the $45.4 \%$ of communities in our survey). The breakdown by regions is: West, 64.8\%; South, 42.3\%;

25. Inter-Media Mktg., Impact Fees in the Housing Industry (Mar. 19, 1986), reported in Lemov, Passing the Buck, Builder MAG., June 1986, at 72 (copy of complete survey on file with authors). The survey was conducted by the Inter-Media Marketing Company between February 17 and March 6 , 1986, using the Builder magazine subscription list. At the outset of each telephone interview, "impact fees" were defined as "charges levied by government bodies on new housing development to pay capital costs of new facilities, such as roads, schools, and sewers, that may or may not be located on the development site and may or may not be used exclusively by the development paying the fee." Interviewees were also told that impact fees "are not considered a form of land dedication nor are they charged in lieu of land dedication." The results of the telephone interviews were tabulated in two ways: (1) by geographic region (East, South, Central, and West), and (2) by primary building area (central city, suburban ring, and rural). 
Central, $35.2 \%$; and East, $26.5 \%$. The breakdown by primary building areas is: suburban, $50.7 \%$; central city, $37.7 \%$; and rural $31.1 \%$. This confirms the result of our local government survey that impact fees are largely a suburban phenomenon, imposed most frequently in the West and least frequently in the East.

Of the builders paying fees for more than 5 years $(88$ of the 213 respondents), about $66 \%$ said the incidence of fees for on-site facilities had increased during the past 5 years, while $55.7 \%$ said the same for off-site facilities. Again, the largest increases by far in both categories were registered in the West, followed by the Southern, Eastern, and Central States. When asked whether the dollar amount of fees had increased, decreased, or remained about the same during the past 5 years, a vast majority $(81.8 \%)$ said they had increased. These results mirror those of the government survey. The regional breakdowns are: West, $94.3 \%$; South, $82.6 \%$; East, $77.8 \%$; and Central, $61.9 \%$. The trend shows a high increase in fee amounts in all 3 primary building areas.

When asked how much the cost of impact fees had increased over the past 5 years, nearly half of the 72 responding builders replied that the cost of impact fees had increased more than $40 \%$, about a quarter said the fees had increased between $20 \%$ and $40 \%$, approximately $22 \%$ of the builders said the increase was less than $20 \%$, and $7 \%$ did not know. The East and West experienced the highest rates of increase, while the South and Central States had the lowest rates. ${ }^{26}$

Another important statistic is the impact fees paid per residential unit. In all regions but the West, about half of the builders reported that the total amount of impact fees per unit is $\$ 1,000$ or less. But in the West, $83 \%$ of the builders said the total is more than $\$ 1,000$. Indeed, fees of more than $\$ 3,000$ per unit are paid mostly in the West $(39 \%)$, followed by the Central States $(19 \%)$, South $(12 \%)$, and East $(8 \%) .{ }^{27}$ Nationally, half the builders pay impact fees of between $\$ 1,000$ and $\$ 5,000$ per unit. The totals of fees paid by builders per unit amount to $12 \%$ for under $\$ 500,24 \%$ for $\$ 500-\$ 1,000,37 \%$ for $\$ 1,001-\$ 3,000,13 \%$ for $\$ 3,001-\$ 5,000$, and $10 \%$ for more than $\$ 5,000$. Four percent of the builders did not know how much they paid per unit. ${ }^{28}$

Two other findings bear comment. Of the 213 respondents now paying impact fees, a full $58.7 \%$ began paying only within the last five years. ${ }^{29}$ An overwhelming $89.2 \%$ answered "yes" to the question "Do you pass on the cost of impact fees to your buyers?" 30 Thus, impact fees are not only

26. Inter-Media Mktg., supra note 25, at 13. The rates of increase were: East, 57.1\%; West, $54.6 \%$; Central, $38.5 \%$; and South, $31.6 \%$.

27. Id. at 17. Although 1 to $3 \%$ of the builders in the Southern, Central, and Western States did not know the amount of impact fees they paid per unit, $23 \%$ of respondents from the Eastern States did not know.

28. Id.

29. Id. at 23.

30. Id. at 18 . 
relatively new and escalating but, in the end, are paid for by the new home buyer.

The surveys reported here reveal that reliance for financing capital costs of community facilities is increasingly being shifted from the general public tax base to a discrete segment of the public: those citizens buying and renting newly constructed housing. This trend toward economic balkanization among communities in America portends serious social problems and disjunctions, particularly when juxtaposed with the economic centralization occurring in the technological, industrial, and agricultural spheres of the private sector. Impact fees are no panacea for local fiscal problems. Because high fees and excessive exactions enhance economic barriers within communities and ignore the beneficial ripple effect of natural growth on regional economies, they effectively zone out increasing numbers of nonaffluent citizens.

\section{APPENDIX}

\section{Responding Communities}

Alabama

Anniston

Jefferson County

Tuscaloosa

Alaska

Anchorage

Juneau

Ketchikan Gateway Borough

Arizona

Gilbert

Mesa

Page

Tempe

Califormia

Alameda County

Arcadia

Atascadero

Azusa

Bellflower

Burlingame

Chino

Cypress

Desert Hot Springs

El Segundo

Eureka
Freemont

Huntington Park

Laguna Beach

Lancaster

Modesto

Merced County

Morro Bay

National City

Ontario

Oxnard

Palo Alto

Placentia

Placer County

Poway

Riverside

Richmond

Sacramento

Santa Clara

Santa Rosa

Stockton

Thousand Oaks

Vista

Colorado

Aurora

Boulder County

Colorado Springs 
Denver

Durango

Glenwood Springs

Loveland

Louisville

Parker

Mesa County

Moffat County

Westminster

Wheat Ridge

Winter Park

Connecticut

East Hampton

Norwalk

Westport

Florida

Ft. Lauderdale

Hollywood

Oakland Park

Pensacola

Port Orange

St. Petersburg Beach

Titusville

Georgia

Camden County

Hawaii

Hawaii County

Idaho

Twin Falls

Illinois

Bowling Brook

Carbondale

Crystal Lake

Decatur

Evanston

Hazel Crest

Mt. Prospect

Park Forest

Peoria

Rockford

Westmont

Indiana
City of Columbia \& Bartholomew County

Indianapolis

Iowa

Ames

Cedar Rapids

Des Moines

Newton

Mason City

Waterloo

Kansas

Andover

Lawrence

Manhattan

Salina

Topeka

Wichita

Kentucky

Bowling Green

Louisiana

Lafayette

Maine

Sanford

Maryland

Howard County

Prince George's County

St. Mary's County

Massachusetts

Bedford

Concord

Northampton

Wellesley

Michigan

Ann Arbor

Antrim County

Bay City

Delta Charter Township

Grand Rapids

Kalamazoo

Marquette

Midland 
Pontiac

Minnesota

Brooklyn Park

Golden Valley

Princeton

St. Paul

Mississippi

Jackson

Jackson County

Missouri

Branson

Columbia

Independence

Montana

Great Falls

Nebraska

Bellevue

Columbus

Omaha

Nevada

Clark County

New Hampshire

Keene

New Jersey

Gloucester County

Vineland

New Mexico

Farmington

New York

New Rochelle

Niagra County

Thompkins County

North Carolina

Clinton

Cumberland County

Guilford County

Greensboro

Greenville

High Point
New Hanover County

Rockingham

Rocky Mount

Wilson County

Ohio

Dayton

Fairborn

Greene County

Middletown

Oklahoma

Enid

Oklahoma City

Woodward

Oregon

Coos County

Forest Grove

Salem

Pennsylvania

Clarion County

Dauphin

Lehigh-Northampton

Counties Joint

Planning Comm'n

York

Rhode Island

Pawtucket

South Carolina

Anderson

Greenville

Myrtle Beach

North Myrtle Beach

Tennessee

Kingsport

Knoxville County

Oak Ridge

Texas

Abilene

Austin

DeSoto

Ft. Worth

Galveston 
Irving

Lubbock

Lufkin

Plano

Port Arthur

San Angelo

Victoria

Wichita Falls

Utah

Davis County

Tooele County

West Valley City

Vermont

Rutland

Virginia

Bland, Carroll, Grayson, Smith, Wythe, Washington Counties

Chesterfield County

Goochland

Lynchburg

Poquoson

Portsmouth

Spotsylvania County

Surry County

Virginia Beach

Washington

King County

Port Angeles
Tacoma

Walla Walla County

Whitman County

Yakima County

Wisconsin

Appleton

Fond du Lac

Green Bay

Janesville

Kankauna

Kenosha

Madison

Manitowoc

Oak Creek

Racine

Rock County

Sheboygan

Wausau

West Virginia

Beckley

Fairmont

Parkersburg

Wyoming

Cheyenne \& Laramie Counties

Gillette

Sweetwater County

Thermopolis

Uinta County 